\title{
Preface
}

When the first edition of this book appeared in the fall of 1959 , it had been preceded by many other histories of California and the cities and towns around San Francisco Bay, but none of these earlier volumes had focused sharply and exclusively on the physical growth and development of the nine counties bordering on the great estuarial system - the metropolitan region generally recognized as constituting the San Francisco Bay Area. The work was a pioneer effort to trace the influence of time and geography on the planning and replanning of cities and to delineate the emergence of an interdependent, closely linked metropolitan complex extending into the several valleys whose watercourses drain into the bay.

Published in a small edition, the book was out of print in a few years and unavailable to the public except in libraries. In time it disappeared from some of these institutions, to the frustration of many people who wished to make use of it. In recent years rare book dealers have advertised for copies at the request of patrons who have had some particular need for the work. I am therefore pleased that the University of California Press has decided to publish a second edition, as a historical document, with no changes in the original text but with an additional chapter summarizing developments of the past twenty-five years. All too rarely does an author have an opportunity to reflect on what he has previously written and to continue his historical account, lending further perspective to the perspective he had formerly deemed relatively broad.

Early in the 1970's one of the editors of the Press asked me to consider preparing a new edition of the book, but for numerous personal reasons I did not wish to undertake the work. Now, more than a decade later, I am indeed glad that I declined. Hindsight has shown that many important movements were then in midcourse, their outcomes uncertain; others had not yet gathered enough momentum to be clearly discernible as irreversible changes that would decisively affect the entire region. The conclusion is inescapable that one should not attempt to update history until a sufficient span of time has elasped - a generation, or approximately a quarter century.

Readers doubtless will note that there is some shift of emphasis in the new chapter, with less attention given to the evolving physical form of the metropolitan conurbation and more to the governmental agencies responsible for guiding the uses of land and the development of the transportation systems serving the various parts. The reason for this change in approach is that governments of all kinds-local, regional, state, and national - have become much more influential than they were in the 1950's, when the main text of the book was written. Moreover, several new regional agencies have appeared on the scene, each exercising a function not previously considered essential. The multiplication of agencies and programs reflects the growing complexity of metropolitan affairs, the increase in population, the advent of new technologies and new problems, and the greater public awareness of the need for regulation to protect valuable natural resources and scenic assets.

In the preface to the first edition I questioned whether the majority of residents of the Bay Area thought of the region as a single entity, as did some politicians and some outstand- 
ing business and professional leaders. And one of my reasons for wanting to write a history of the area was to disseminate knowledge of how it had become an interrelated community. "If history demonstrates anything," I wrote, "it demonstrates that great achievement, civic or national, is possible only when all elements of a society are conscious of a common heritage and enjoy the prospects of individual benefit in a future to which all contribute." I should like to think that in the past two and a half decades the number of residents who are capable of thinking regionally has tellingly increased, since freeways and transit systems enable people to travel more widely and since the decisions of regional agencies have a more direct bearing on their lives. Sectionalism persists, to be sure, but in such matters as the control of air and water pollution, transportation, the preservation of San Francisco Bay, and the long-term assurance of adequate water supplies, people more and more are obliged to take an areawide view. In such matters they must voice their concerns to regional boards, or at least to subregional agencies whose policies reflect consideration of the welfare of the metropolitan population. If the region has not yet been welded into a cohesive urban community, it is certainly a good deal less hampered by political boundary lines and geographic barriers than it was at the beginning of the 'sixties, as I have sought to show in the new final chapter.

Endeavoring to bring any history up to date is a bit like trying to take a photograph of a wriggling youngster. Something is going to be blurred. The significance of trends and events cannot be fully understood or even divined. So one hazards interpretations and indulges in tentative forecasts, knowing that time may reveal them to be partly or altogether erroneous. Some persons would say, furthermore, that a writer of history has no business making projections into the future, but should be content with illuminating the past. So dynamic is the San Francisco Bay Area, however, that the temptation to speculate on the next ten or fifteen years is irresistible. The new chapter therefore concludes with a few observations about the prospects of the region, based on consideration of certain developments that seem prophetic.

For readers who would like a view of the region not limited mainly to its physical organization, I should like to mention a collection of short essays recently issued by the Institute of Governmental Studies at the University of California, Berkeley (with which I was associated during most of the 1960's and to whose staff I am indebted for much assistance in producing the additional chapter). Golden Gate Metropolis, by Charles Wollenberg, does not pretend to be a comprehensive history of the Bay Area, even though it sweeps along from the period of Spanish settlement in lands occupied for centuries by Native Americans to the Gold Rush, the era of clipper ships, the coming of the railroads, the violent earthquake of 1906 , and on through the present century to the tumultuous 'sixties and the volatile activities of Silicon Valley in the 'seventies and early 'eighties. Wollenberg is fascinated, above all, by the individuals and groups who helped to make Bay Area history, and his essays are rich in human interest. The perspective throughout is regional, making the collection fortuitously complementary to this volume.

Many of the persons who aided me with my research in the 1950's and gave me valuable advice after reading preliminary drafts are no longer living and probably would not be known to most present-day readers, but a few colleagues at the University of California, Berkeley, to whom I expressed gratitude in my original preface are still deeply involved in regional activities and have been as generous as ever in helping me prepare a concise account of developments in recent decades. Victor Jones, professor emeritus of political science, not only lent me several of his own papers on regional governance but also suggested many other sources of information, read and criticized drafts, and acted as chief counsel and sparring partner. T. J. Kent, Jr., who was chairman of the Department of City and Regional Planning when I began work on this history in the early 'fifties and is now a professor emeritus, has offered detailed criticism of the new chapter and has provided welcome information about People for Open Space, on whose executive committee he serves. Corwin Mocine, also a professor emeritus of city and regional planning, reviewed the manuscript of the new chapter and gave suggestions based on his own extensive experience in the area.

My friends Eugene C. Lee and Stanley Scott, director and assistant director, respectively, of the Institute of Governmental Studies, permitted me to use their own and several student papers which provided information about the activities of important regional agencies. Scott, author of Governing California's Coast and editor of an Institute publication on coastal conservation, also answered questions about the programs of the state and regional coastal commissions.

I wish to thank Daniel Luten, formerly a lecturer in the Department of Geography on the Berkeley campus, for giving me the benefit of his specialized knowledge of the metropolitan region.

To Lawrence D. Dahms, executive director of the Metropolitan Transportation Commission, I am indebted for reviewing a draft of the section on the commission and for providing some details I needed. Dian Gillmar, information coordinator of the agency, made available many annual reports and copies of speeches by Mr. Dahms that were especially helpful to me. In addition, she lent me documents in the commission's library that I found useful.

Patricia R. Perry, coordinator of the Census Center of the 
Association of Bay Area Governments, and Nora Juarbe, a member of the staff of the San Francisco Bay Area Council, readily responded to my requests for analyses of census data.

In preparing the section on regional parks, I made use of reports and data provided by Eugene Erba, program analyst of the California Department of Parks and Recreation; Linda L. Chew, development administrator of the East Bay Regional Park District; Charlotte MacDonald, public communications coordinator of the Midpeninsula Regional Open Space District; and Barbara Ott, a member of the staff of the Santa Clara County Planning Department. I thank them for their cooperation.

Brian Wilson, a member of the Save San Francisco Bay Association, generously consented to compile a summary of major permits issued by the Bay Conservation and Development Commission from 1974 to 1983.

Sonny M. Ismail, public relations representative of the Port of Oakland, provided information about the growth of the port in recent decades, together with photographs of port terminals. I appreciate his assistance.

I have drawn so liberally on a few works that I wish to express special indebtedness to the authors and to list their names and the titles of their studies here rather than in the bibliography: Deidre A. Heitman, The Association of Bay Area Governments: A Critical Look at the Bay Area's Regional Planning Agency, a University of California, Berkeley, senior honors thesis in a political science course offered by Professors Lee and Jones in 1982; John Martin Eells, Local Agency Formation Commission Spheres of Influence: Effective Planning for the Urban Fringe?, a University of Cali- fornia, Berkeley, master's thesis in the Department of City and Regional Planning, issued in 1977 as Working Paper 773 by the Institute of Governmental Studies; David W. Jones, Jr., Robert Taggart, and Edith Dorosin, The Metropolitan Transportation Commission: An Innovative Experiment in Incremental Planning; A Cautious Experiment in Regionalism, Stanford Transportation Research Program, Stanford University, August, 1974.

The passage of time has not diminished my appreciation of the help Charles Richard Dunann gave me as my research assistant when I was writing this book in the 1950's. The handsome historical maps he prepared to illustrate the volume continue to be one of its best features.

Since Dorothy Huggins, who edited the first edition, is still enjoying life, I wish to thank her again for ironing out inconsistencies of style, punctuation, and capitalization and for insisting that $I$ rewrite some awkward sentences. She was a most capable editor, paying meticulous attention to detail.

I hardly know how to thank James H. Clark, director of the University of California Press, and William J. McClung, editorial director, for their willingness to reissue this history with a new preface and an additional chapter. Their confidence that there is a new readership for the book has lightened the work of compressing the developments of the past twenty-five years into a limited number of pages. May their faith in the venture be well rewarded.

I especially appreciate the very capable editorial services of Sheila Levine and Mary Renaud, who guided this preface and the last chapter from manuscript to printed page.

Mel ScotT 



\section{The San Francisco Bay Area}


